\title{
Kinematics associated with foot pronation in individuals with patellofemoral pain syndrome: a case-control study
}

\author{
Christian J Barton, Pazit Levinger , Kate E Webster, Hylton B Menz \\ From Australasian Podiatry Council Conference 2011 \\ Melbourne, Australia. 26-29 April 2011
}

\section{Background}

Excessive foot pronation during gait is frequently linked to patellofemoral pain syndrome (PFPS) development, due a proposed coupling of increased foot pronation with increased tibial and femoral internal rotation. However, there is a paucity of research which has compared kinematics associated with foot pronation between individuals with PFPS and controls. The aim of this study was to compare forefoot, rearfoot and tibial kinematics associated with foot pronation between individuals with PFPS and controls.

\section{Methods}

Twenty-six individuals with PFPS (5 males and 21 females) and 20 controls (4 males and 16 females) aged between 18 and 35 were recruited. Three dimensional motion data was collected during natural comfortable walking using the Vicon motion analysis system incorporating the Oxford Foot Model. Between-group comparisons were made for magnitude and timing of peak angles, and range of motion at the forefoot (dorsiflexion and abduction), rearfoot (eversion) and tibia (internal rotation).

\section{Results}

The PFPS group exhibited a trend towards slower walking velocity, $(p=0.07)$ so due to the potential of this to influence kinematics, all comparisons between the groups were adjusted for velocity. The PFPS group demonstrated earlier peak rearfoot eversion relative to the laboratory $(30.4 \%$ versus $35.3 \%$ of the gait cycle, $\mathrm{p}=$ $0.01)$ and relative to the tibia ( $32.7 \%$ versus $36.5 \%$ of the

* Correspondence: p.levinger@latrobe.edu.au

Musculoskeletal Research Centre, Faculty of Health Sciences, La Trobe University, Bundoora, Victoria 3086, Australia gait cycle, $\mathrm{p}=0.03)$. Effect sizes for these timing differences were $-0.83(-1.42$ to -0.21$)$ and $-0.66(-1.24$ to -0.05), respectively. No significant differences were found for any variables associated with forefoot or tibial motion.

\section{Conclusions}

Earlier peak rearfoot eversion in individuals with PFPS may indicate more rapid foot pronation following heel strike when walking. Due to the potential influence of this on knee and patellofemoral joint loading, this may be a factor related to the pathomechanics of PFPS development.

Published: 20 May 2011

doi:10.1186/1757-1146-4-S1-O4

Cite this article as: Barton et al:: Kinematics associated with foot pronation in individuals with patellofemoral pain syndrome: a casecontrol study. Journal of Foot and Ankle Research 2011 4(Suppl 1):O4.

Submit your next manuscript to BioMed Central and take full advantage of:

- Convenient online submission

- Thorough peer review

- No space constraints or color figure charges

- Immediate publication on acceptance

- Inclusion in PubMed, CAS, Scopus and Google Scholar

- Research which is freely available for redistribution

Submit your manuscript at www.biomedcentral.com/submit
() Biomed Central

\section{Biomed Central}

(c) 2011 Barton et al; licensee BioMed Central Ltd. This is an open access article distributed under the terms of the Creative Commons Attribution License (http://creativecommons.org/licenses/by/2.0), which permits unrestricted use, distribution, and reproduction in any medium, provided the original work is properly cited. 